\title{
The Post-Shakespearean Body Politic in Jeff Noon's Vurt
}

\section{Sujata lyengar}

\section{(2) OpenEdition \\ Journals}

\section{Electronic version}

URL: http://journals.openedition.org/shakespeare/3546

DOI: 10.4000/shakespeare.3546

ISSN: 2271-6424

\section{Publisher}

Société Française Shakespeare

\section{Electronic reference}

Sujata lyengar, "The Post-Shakespearean Body Politic in Jeff Noon's Vurt », Actes des congrès de la Société française Shakespeare [Online], 33 | 2015, Online since 10 November 2015, connection on 04 June 2020. URL : http://journals.openedition.org/shakespeare/3546 ; DOI : https://doi.org/10.4000/ shakespeare.3546

This text was automatically generated on 3 June 2020 .

(c) SFS 


\title{
The Post-Shakespearean Body Politic in Jeff Noon's Vurt
}

\author{
Sujata lyengar
}

\section{Introduction}

1 Jeff Noon's 1993 Vurt was hailed as one of the first British cyberpunk novels, ${ }^{1}$ but Noon himself prefers his own coinage, "avant-pulp" because Vurt refuses to explain itself or to provide laws of science or nature on which it runs. ${ }^{2}$ Moreover, where cyberpunk's beings are post-human, in the sense suggested by Donna Haraway, Katherine Hayles, and others, prosthetic or virtual bodies in Noon's Vurt retain the heft and embrace of the Newtonian world, the physical universe that William Gibson's novel Neuromancer contemptuously dismisses as "meat". ${ }^{3}$ For Haraway and Hayles, the post-human self derives not from a transcendent or unified subjectivity but from a diverse and divergent consciousness distributed among multiple objects, languages, computer programs, prostheses, and other extensions of the human. Elsewhere, Hayles writes that the creation (or imposition) of a coherent narrative upon the overwhelming data streams of everyday life in physical and virtual environments, and our attribution of identity to non-human artefacts (such as the flickering avatar in a game of Pac-Man) distinguishes a post-human subject that is always technically and technologically mediated. ${ }^{4}$

2 Although a cult favorite, Vurt is unfamiliar to most Shakespeareans, so I offer here a brief overview. Vurt's post-humanism responds to technological innovation and computer language; to the ongoing scientific investigation of what distinguishes human beings from other animals; and to the ubiquitous racialized language that associates black skin pejoratively with animality in works of English literature, including in Shakespeare's Othello. In Noon's novel the Vurt (or virtual game-universe) co-exists alongside a world of interspecies inhabitants high on a variety of legal and illegal, "vurtual" dreams, enjoyed by sucking on a "feather". Blue feathers are legal lullabies, safe escapes from daily bleakness. Black feathers, illegal but soft, enhance 
pain and fear. Pink feathers take the user into dripping Pornovurts, Silvers allow users to mix and match, and Yellows-most dangerous of all-provide no escape from the Vurtual world until or unless the user wins the game. Additionally, those playing Yellow run the risk of being swapped-trapped in the Vurt world, randomly exchanged for a Vurtual creature of approximately equal worth. This unwelcome exchange has taken place before the novel begins. Scribble is seeking his true love, Desdemona, who also happens to be his sister. Swallowed up by the "Curious Yellow" feather she has consumed while inside the "English Voodoo" feather (thus entering an inescapable meta-Vurt), Desdemona endlessly relives a nightmarish version of her past. "Curious Yellow" alludes both to the 1960s underground pornographic film "I Am Curious Yellow" and to Alice's "curiouser and curiouser" adventures in Wonderland (an important inter-text for Noon in the series of books set in the Vurt universe, which includes Pollen, The Automated Alice, and Nymphomation). ${ }^{5}$ In Vurt, Desdemona has been exchanged for the homesick, hideous "Thing-from-Outer-Space," an amorphous blob of animated, sentient yet dumbly powerless Vurtual matter.

Inhabitants of Noon's world inhabit five "levels of being." First-level beings are "pure" modes: dog, human, robo, shadow and vurt. Robos are physically strong, almost invulnerable, and often become wilfully homeless; Shadows smokily enter and manipulate other minds and often become detectives; Dogs exude sexual energy, unthinking pack loyalty, and often become major rock stars; Humans are much what they ever were, and Vurt beings can be or become anything you, or they, desire. Each subsequent level, however, involves a further degree of miscegenation: second-level beings combine two elements (for example, robodog, vurtman, shadowdog, roboman); third-level beings combine three (for example, Robovurtdog, Shadowmanvurt, Robodogshadow); fourth-level modes are only missing one element, and go by fanciful names such as Flake, Dunce, Squid, Spanner and Float. The final level is the fifth, where beings have "a thousand names because everybody calls them something different". ${ }^{6}$ Most creatures are second level or third level; fifth-level beings are so rare that few people have even encountered one.

\section{Post-Humans and Other Animals}

4 This world of promiscuous species-mixing and technological body modification consistently queries what it means to be a person or a human. Daniel Gilbert jokingly suggests in his popular Stumbling Upon Happiness that every psychologist attempts at least once in his or her career to complete the sentence, "The human being is the only animal that...". ${ }^{7}$ Various historical attempts to attribute human uniqueness to language acquisition, tool use, learned culture, and other traits have increasingly over the second half of the twentieth century and the first decades of the twenty-first found these activities and skills among other animals, too. ${ }^{8}$ Gilbert concludes that what might distinguish us is our ability to envisage ourselves in past, present, and future, and to imagine possible futures for ourselves. ' Thus science-fiction, whether "hard" or "soft", might prove a form that enshrines the quintessentially human despite its reliance upon technological or non-human enterprises. "Hard" science-fiction, as Katherine Cramer observes, adheres more closely to existing scientific knowledge than does "soft" science-fiction, which can include elements of fantasy; Cramer additionally identifies cyberpunk as initially a branch of "radical hard SF" that developed into a genre with 
"specific literary furniture and a fetish for new technology". ${ }^{10}$ Where, however, classic cyberpunk dramatizes our discomfort with the prosthetic or the non-human, what Derrida (adapting Rousseau) called "that dangerous supplement", Vurt demolishes biological or genetic species segregation but retains social or cultural racial differences. ${ }^{11}$ Post humans in Vurt cherish notions of purity (racial, specific, technological, pharmaceutical) that seem to propel the plot but the disintegration of which proves essential for that plot's dénouement.

5 This dystopian, technologically mediated, inter-species, druggy world might seem very far from Shakespeare, but Noon redeploys classic literary intertexts, notably Othello, within Vurt to create this ambiguously post-human, yet still racialized, space. Vurt and Othello both use the figure of the animal on the one hand and the supplement or prosthetic of drugs or alcohol on the other to interrogate what it means to be a human being. Forthcoming work on Othello and the post-human suggests that, as Steven Swabrick puts it, it is at the textual instances where animality and animals appear and human beings disappear in Othello that human, social, discursive race emerges. Swarbrick's sophisticated essay, "Shakespeare's Blush, or 'the Animal' in Othello", deconstructs the language associated with both blackness and animals in Othello (from the "goats and monkeys" whom Iago evokes salaciously and Othello furiously to the " old black ram", "coursers" and "jennets" to which Iago compares him or to the "cats and blind puppies" that the latter imagines drowning ${ }^{12}$ ) as part of a nexus that attributes shame or blushing to the human and shamelessness to the animal. ${ }^{13}$ Swarbrick's larger argument synthesizes recent studies of early modern animals that have considered human-animal relations within the context of colonial, raced, and gendered power with the so-called eco-critical turn in Shakespeare studies that considers humans and animals as part of a complexly and mutally interdependent, selfcreating environment. ${ }^{14}$ Swarbrick extends Joel Altman's germinal argument (to which I shall return later in this piece) about the ways in which Iago uses the rhetorically probable or provable to convince Othello of Desdemona's guilt after-the-fact and to leave Othello no rhetorically plausible self within the play outside Iago's own linguistic constructions. ${ }^{15}$ Iago's language of probability and the provable overlaps, Swarbrick suggests, with the performative disappearance of visible shame, understood through the discourse of blushing (considered in the period a characteristic of light-skinned persons but not of darker-skinned peoples or of animals) and in the play also through the importance of showing or demonstrating guilt or innocence. Swarbrick concludes that the collapse of shame as a fundamental shared human characteristic marks the convergence of the difference between human and animal, and that this breakdown of the human as an ontological category identifies the emergence of race. ${ }^{16}$ David Houston Wood's essay “'Fluster'd with flowing cups': Alcoholism, Humoralism, and the Prosthetic Narrative in Othello" identifies Cassio's susceptibility to alcohol as a "prosthetic" narrative device (following David Mitchell and Sharon Snyder's coinage), a tendency that diverts the narrative away from a focus on Othello's self-evident visible difference and instead alerts us to Iago's manipulation of melancholy or black bile and to how the play figures "deviancy[as ...] simultaneously an explicit and latent feature involving both racial difference and contemporary concepts of inward aberration." ${ }^{17}$ This diversion or redirected "deviancy" once more (as Cassio himself observes) confuses men and "beasts" (Othello, II.iii.286). 


\section{Fantastic and Marvelous Adaptation}

6 The fundamental logic of both Vurt and Othello depends upon the way that Iago manipulates prior rhetorical and social structures (probability, shame, drunkenness) in order to fantasize a notion of the human as something that definitively excludes Othello and Desdemona-or perhaps, as a set of relations from which he himself chooses to stay apart. In this sense both Vurt and Othello are resolutely fantastic, in Tzvetan Todorov's sense. Todorov's fantastic combines the uncanny (which evokes in distorted or magnified form the rules of the real world) and the marvelous (which defies all diegetic explanation). Todorov argues that science fiction involves a process of "adaptation": "at first confronted with a supernatural event, [the reader] ends by acknowledging its "naturalness." 18 Shakespeareans might note that such a sense of "adaptation" emphasizes the ways in which the reader or consumer is herself changed by the artistic or literary object; in this way, Todorov's formulation anticipates current critical movements to redefine the process of adaptation or appropriation and to remove the study of appropriations from the so-called fidelity criticism that dominated the last century. Such critics, such as Linda Hutcheon and Siobhan O'Flynn, consider adaptation and appropriation as points on a "continuum" of interwoven textual and cultural references; moreover, they argue that an adaptation need not refer to a secondary, belated, or inferior derivative based on a primary, earlier, and superior original but instead to cultural productions worthy of study in their own right and for their own sakes. ${ }^{19}$

7 An influential article by Hutcheon and Gary R. Bortolotti suggests that we redefine our understanding of "adaptation" in order to take account of biological or genetic senses of the term that foreground the ability of the text to "replicate" itself under different circumstances and conditions. ${ }^{20}$ As Christy Desmet and I have observed, however, Bortolotti and Hutcheon nonetheless enshrine agency or intentionality at the core of successful replication and thereby privilege once more the binary of chronologically prior source and temporally later target domain. ${ }^{21}$ Douglas Lanier, in contrast, adapts Gilles Deleuze and Felix Guattari to develop a Shakespearean "rhizomatics" or "process of becoming", in which Shakespearean adaptations proliferate without or almost despite active authorial or human agency. ${ }^{22}$ Desmet and I suggest that the term "appropriation" can emerge as a process that changes the meaning and import of prior and later texts but that most importantly contributes to the fashioning of the self: "To appropriate something is to make it one's own, part of oneself, not just one's property". ${ }^{23}$ I add here that such appropriations remake both past and present, that as such they constitute another process through which we make ourselves human. This subjectmaking property appears even more pronounced in science fiction or imagined future and para-worlds, through and in the realm of the fantastic, as we relive our "uncanny" past selves and project "marvelous" or unimaginable future selves. ${ }^{24}$

Vurt, however, corresponds more closely to Todorov's earlier, broader definition of the fantastic, as "an evanescent genre" that hesitates between the uncanny and the marvelous and that includes writerly references to its own "hesitation" between real and imaginary worlds. ${ }^{25}$ The true fantastic, he suggests, is

in its pure state [...] represented by the median line separating the fantasticuncanny from the fantastic-marvelous. This line corresponds perfectly to the nature of the fantastic, a frontier between two adjacent realms. ${ }^{26}$ 
Vurt is uncanny, recalling the real world to its readers (to Mancunians, in particular, by its detailed, street-level mapping of the city) and marvelous, since these frontiers in Vurt border virtual and real worlds, species boundaries, bodily edges and orifices, timestreams, and socio-ethnic neighborhoods. The novel maps out a cognitive dismay at the post-human blurring of barriers of species-difference on to the body politic of $1990 \mathrm{~s}$ Manchester.

9 The drug-induced Vurt is itself uncanny and marvelous: its "hauntings," the memories of the real world that force users to remember that they are only enjoying a dream, are uncanny; its existence itself is marvelous. The name of the narrator, Scribble, selfconsciously alludes to the novel's own writing, to the extent that when Scribble briefly tries to go straight, giving up both drugs and "dripfeed" (welfare) by working as a DJ, he takes for himself the moniker "Ink MC", a sobriquet that also indirectly recalls the imagery of books, paper and contaminating ink that that surrounds Shakespeare's Desdemona in Othello. ${ }^{27}$ In the Sagittary, the Duke reassures Brabantio:

DUKE. [...] the bloody book of law

You shall yourself read in the bitter letter

After your own sense...

Othello, I.iii.67-69

Later, Othello famously "bewhore[s]" his wife and compares her to a blank page inscribed with obscenity:

OTHELLO. Was this most fair paper, this most goodly book,

Made to write "whore" upon?

Othello, IV.ii.73-74

Both novel and Vurt later represent the story through a "remediation" (to borrow Jay David Bolter and Richard Grusin's useful term) when Scribble turns his adventures into a Vurtual feather. ${ }^{28}$ Even the idea of the "feather" itself records the to-us archaic recording instrument of the quill pen, which appears on some versions of the novel's cover. And just as the Vurt, its world and its telling are uncanny and marvelous, so, too, is its understanding of race: uncannily recalling both the racialized, segregated geography of Manchester in the 1990s and its tragic Shakespearean intertext, and marvelously predicting inter-racial and inter-species coalition and reframing Othello as a comedy of love. ${ }^{29}$

\section{Mapping Race in Vurtual Bodies Politic}

This cognitive remapping of Britishness and race translates into the physical, racialized roadscape of 1990s Manchester. Detailed street maps from the decade (called in the US "key maps" and known as the "A to Z" in British English) of Manchester in the 1990s and the Manchester census from 1991, which asked respondents to denote their racial/ ethnic identification and plotted the results on maps of the districts of central Manchester, support my contention that Vurt oscillates between an uncanny and a marvelous understanding of what we call race, and another way to look at what Shakespeare does in Othello. ${ }^{30}$ Vurt also offers an embodied geography in a microcosmic sense, mapping the modified human body on to the body politic of Manchester. Where Vurt's fantastic world can be tracked in real-life and then-contemporary locations (Figure 1), what François Laroque has called Shakespeare's "imaginary geography" and in particular Othello's "mental cartography that transcends the enclosed world of the domestic tragedy is clearly to be found in the suburbs of hell". ${ }^{31}$ 


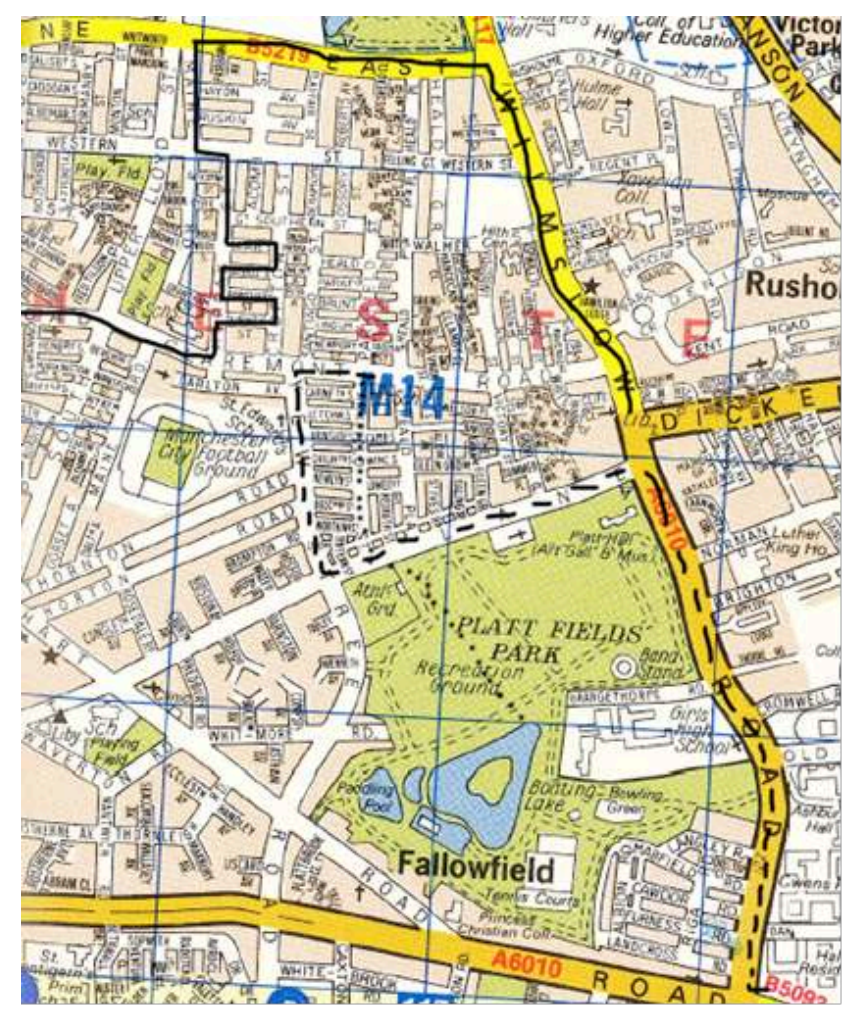

Figure 1: The Stash Riders' peregrinations, mapped on the Manchester A-Z.

REPRODUCED BY PERMISSION OF GEOgRAPHERS' A-Z MAP CO. LTD.

(C)CROWN COPYRIgHT AND DATABASE RIgHTS 2015 ORDNANCE SURVEY 100017302

Key: Solid line: Vurt, p. 9; dashed line: Vurt, p. 273; dotted line: Vurt, p. 303

Andrew Wenaus helpfully identifies the geography of the Vurtual world as "fractal", a "paraspace", infinitely looping and regressive, within a universe that is "paralogical". Wenaus suggests:

paralogy is an inventive hermeneutics that privileges local over global knowledge and promotes a shift from universal grand narratives to localized small narratives.

A paralogical argument is in a continual state of change-final consensus is impossible, though agreement may occur provisionally-and legitimation of ideas is subject to perpetual debate. ${ }^{32}$

Argument in Othello, too, is provisional, contingent, ever-shifting, and both continuously and retroactively constructed, preposterously, as both Patricia Parker and Joel Altman have suggested. Parker deftly deconstructs the rhetorical figure of hysteron proteron, or the preposterous, the "racist logic" that automatically identifies the union of Othello and Desdemona as unnatural or out of order, and the "syllogisms" of Iago that present the play's tragic outcome as, in what Parker reminds us are his words, as a "foregone conclusion". ${ }^{33}$ Altman argues that both Iago and Othello forge their identities in the furnace of rhetoric; Iago restricts the rhetoric available to Othello moment by moment so that the latter finds his potential subject-positions limited by what Iago has already expressed and foreclosed. Dennis Britton further recontextualizes Iago's shifting rhetoric of the local in light of debates surrounding the religious conversion of dark-skinned believers and the efficacy of adult baptism. Britton notes astutely that Iago prioritizes Othello's racial and religious differences in turn, pressing on whichever one renders the general more rhetorically and culturally alien from his surroundings. ${ }^{34}$ 
Iago traps Othello into a paralogical world -- almost, we might say, remembering its mystical geography, a virtual one. "Perpetual debate", to return to Wenaus's formulation, surrounds the motivation of both Othello and Iago, and Iago's meaningmaking indeed "privileges local over global knowledge". Othello's famous "music", and his logic, turn to the world, the globe, the universe, the cosmos, for truth. When Othello exclaims,

OTHELLO. If she be false, $\mathrm{O}$ then heaven mocks itself!

I'll not believe it.

Othello, III.iii.282-283

his expression of faith encompasses a "world of chrysolite", an "entire and perfect" universe, in its breadth (V.ii.152-153). Iago, in contrast, insinuates the superiority of his own hyper-local knowledge to Othello's expansive imaginary realm.

IAGO. I know our country disposition well.

In Venice they do let God see the pranks

They dare not show their husbands; their best conscience

Is not to leave't undone, but keep't unknown.

Othello, III.iii.205-208

Iago here claims to know both the tricks of "super-subtle Venetian" courtesans and the immediate and intimate knowledge of the body allegedly revealed by Cassio's "loose" night-time embrace; he offers a purported road map to the "erring barbarian" Othello (I.ii.355; III.iii.421; II.ii.354). And it is worth noting briefly that this play is full of items that are lost or imagined to be lost, and persons who have lost their way. Brabantio's has "lost half [his] soul" in Desdemona, and he retorts by asking if Rodrigo has "lost [his] wits"; Cassio fears he "lost us [Othello] on a dangerous sea" when he "lost his company"; Iago feigns a desire to have "lost / [his] legs" in action rather than witnessing Cassio's reputation "lost", and Desdemona wishes vainly to have "lost her purse / Full of crusadoes" than her handkerchief (I.i.87, 92; II.i.47, 92; II.iii.179-80, 256; III.iv.25-6). Most plaintive perhaps are Desdemona's cry, "I know not how I lost him" and Emilia's determination to avenge her mistress "Though [she] lost twenty lives" (IV.ii.155; V.ii.153). Othello himself imagines he has lost his way:

OTHELLO. Here is my journey's end, here is my butt,

And very sea-mark of my utmost sail.

Do you go back dismay'd? 'tis a lost fear;

Man but a rush against Othello's breast,

And he retires. Where should Othello go?

Othello, V.ii.274-278

"Journey's end" might suggest that Othello has had a destination in mind all along, but a "sea-mark" denotes a buoy or marker affixed to a rock or a point on the sea-bed on the open sea, or the mark of highest tide, that land that can be covered or washed away. His plaintive question, "Where should Othello go?" implies that he can navigate no further, having reached the end of the map, the end of the world.

Vurt and Othello both seem to circumscribe sexual reproduction and physical or virtual travel by the barriers of race. In Othello racial difference comes into being through sexual, religious, cultural and other differences, including the animal-human divide; in Vurt "race" (so-called by the novel) seems to persist even as other kinds of difference, even species-difference, seem to be erased. Vurt uses the word race in two senses, both as species-difference, marking dogs, robos, humans and vurt beings from each other, and in its more casual use, to distinguish groups of human beings from one another. Scribble's gang, the Stash Riders (who are themselves, initially, racially unmarked) 
react violently to suggestions that they themselves might be hybrids, prizing themselves on being "pure", remaining hostile to hybrid species and to humans from other races. When Icarus King, a feather-remix engineer and maker of PornoVurts, to whom the Stash Riders have appealed for a sample of Curious Yellow, insists that Scribble is mixed, part-Vurt, Scribble denies it vehemently: "Not me-...'m pure! Tell him I'm pure...!" Beetle, the domineering gang-leader, "can't stand hybrids", and taunts his shadowgirl lover, Brid, with her hybridity. ${ }^{35}$ Faced with a seemingly human family who tear off their skin to display the robotics beneath, Scribble finds himself "almost retching", a reaction that the roboman says is typical of "the pure" ${ }^{36}$ Disgust likewise marks Othello's response to perceived sexual impurity or (deliberately to use an anachronism) miscegenation:

IAGO. [...] her delicate tenderness will find itself abused, begin to heave the gorge, disrelish and abhor the Moor; very nature will instruct her in it and compel her to some second choice.

Othello, I.iii.205-208

16 Where, however, Othello's geographical travels (he is the Moor of Venice) and his "hairbreadth scapes", his emotional and physical travails, combine to win him Desdemona, in Vurt the social, historical barriers of race remain intact and threaten to separate Scribble from his Desdemona. Species-mixing goes on in the Vurt between humans and robos, shadows, vurts and dogs, but not, seemingly, between human beings of different races. Even in post-industrial apocalypse, Noon's Manchester seems to adhere to the racialized geography of the early 1990s. A sign of the "Bottletown" neighborhood's decay is that the "blacks" and "students" (apparently these groups do not overlap) have moved out, "leaving the place to the non-pure" "robo-crusties and shadowgoths". ${ }^{37}$ The climax of the novel occurs near "the curry chute", (a version of Manchester's socalled "curry mile", in Rusholme) where Scribble, the narrator, complains that the "Asian" kids are looking at him "funny". (This is also the first time that Scribble explicitly identifies himself racially, as a "white guy".) ${ }^{38}$

"Asian" in Britain refers to South Asians from the Indian subcontinent, a group that features a variety of physical types, sizes, skin-colors, hair-types, religions, a group united as a category only by point of origin and their perception as "Asians" in Britain. The gang encounter "blacks" and "Asians" less frequently than they cross over into the dangerous, seductive Vurt world, the clinical Robo region "Toytown" or the stinking dog citadel, "Turdsville". In this confusing inter-species universe, it seems still strangely possible to tell instantly if someone is "Asian", or even if they are an Asiandog playing "the deep rhythms of Bhangradog songs" ("Bhangra" is a fusion of Punjabi folk dance and rock). ${ }^{39}$ How can this category, "Asian", like that of "the blacks" remain legible in a Vurtual world where nothing is what it seems?

\section{Race and Purity}

18 The narrator and the gang are not merely unmarked or absent in racial terms, but they also erase historical stories of racial miscegenation. Remember that Scribble's sister is called Desdemona, the name of Othello's slain wife in Shakespeare's tragedy of miscegenation. Othello, the "black" Moor of Venice, kills his "alabaster" wife Desdemona because he has been made to believe that she has been unfaithful (V.ii.5). Both Othello and Desdemona are tricked by "honest Iago", who "hate[s] the Moor" for a 
number of reasons, all of which might be over-determined racially, and that correspond to emergent early modern racial stereotypes: Iago believes that Othello is savage, childlike, gullible and lascivious (I.iii.292). ${ }^{40}$

Scribble's love-story, too, self-consciously rewrites Othello's. Othello dramatizes exogamy, Vurt, endogamy. Gayle Rubin has analyzed the "traffic in women" as the exchange of women between men in order to foster inter-tribal relations; the incest taboo-a ban on endogamy, or inter-marriage-arises in order to encourage exogamymarriage outside the clan-to knit disparate groups together. Women become tokens to be exchanged to foster friendships and alliances between powerful men. ${ }^{41}$ If Shakespeare's Othello is a fable about exogamy taken to its extreme (Desdemona marries a man not only from outside her immediate family or clan, but from outside her "clime, complexion, and degree" [III.iii.234]), then Vurt appears to turn the tale into a fable about endogamy taken to its extremes. The gang's first line-up, before the novel begins, itself forms a microcosm of an incestuous nuclear family: belligerent Beetle as the father, mysterious shadowgirl Brid as the mother, Scribble as the wayward son who occasionally challenges Beetle's authority, and Desdemona in a sibling-like structural relationship to Scribble, but in a relationship that was also sexual-just as when they were teenagers at home. After Desdemona's disappearance, her replacement becomes the object of both Scribble's and Beetle's desires. The relationships between Beetle and his two girlfriends (Brid and Mandy, the hybrid and the human) thus also follow an incestuous, endogamous model; the girls compete over Beetle, who is the most powerful male in the group, and he offers women with whom he is bored to his secondin-command.

Both Desdemona and Scribble at various points re-enact in the Vurt their hideous reallife pasts (both have suffered from childhood abuse, physical and sexual, by their domineering father, who had "pounded" Scribble and "bedded his daughter a few times anyway, along with all the cuttings to her"). ${ }^{42}$ What are we to make of this Vurtual reality, where endogamy is rewarded over exogamy, where social myths such as race persist even after the biological breakdown of species-difference?

Scribble wants to remain "pure" and to retrieve his sister-love and return to endogamy, to the family romance, but as the Game Cat, and, ultimately, the novel claim, it is only through mixing and through racial coalition that creatures can ascend to the next level of the Game. The Game Cat, a recurring character who is at once the catalogue used by serious computer gamers, a feisty feline, a gentleman called Geoffrey and one of the links between the Vurt and real worlds, periodically intrudes into the narrative (in the voice of the catalogue) to explain game rules and to offer advice and warnings: "Be careful. Be very, very careful...." ${ }^{43}$ The Cat's advice provides another way in which the novel engages with the fantastic and with Othello; the Cat offers reader and narrator a series of rules that seem to be rigid, and the Cat appears to observe everything that goes in the Vurt. But the Cat functions as a benign or at least neutral Iago, a stage-director or chorus to Scribble's blundering Othello. The rules often bend or hesitate, and Scribble is able to circumvent them and to elude the Cat's (and the Vurt's) observations in order to access his lost Desdemona.

And in fact the novel hesitates fantastically between the Stash Riders' notion of what it might mean to be "English" (racial and species purity) and an Englishness based on racial coalition. The sexy dogman rock star, Dingo Tush, is on a tour called "Barking for Britain". ${ }^{44}$ Desdemona's original gateway to Curious Yellow is called "English Voodoo", 
described as a pastoral dream of "an English garden", "kissed by the English sun", but this vision of insular, edenic Englishness immediately turns into a nightmare of "pleasure, knowledge" and "pain", with "lots of sex; that special kind, with a delicious English thump", that is, sex inescapably linked with-or even eroticized by-violence. ${ }^{45}$ The Game Cat lives in "A Room in England" heaped up with "swapped objects" such as "kitchen sinks and golf clubs, stuffed animals and antique globes, fishing rods and bus tickets", "all the paraphernalia of England", abandoned in the Vurt. ${ }^{46}$ This insular, antique Englishness has imprisoned Desdemona and can only be conquered by "knowledge", knowledge of the real world and of other human beings and histories as well as of the Vurt.

We can now return (paralogically, perhaps) to the failure of knowing in Othello. Iago entraps Othello in a circumlocutory paraspace of misleading local knowledge. Even a few lines of the so-called temptation scene suffice to indicate this closed-loop logic:

IAGO. Did Michael Cassio, when you wooed my lady,

Know of your love?

OTHELLO. He did, from first to last. Why dost thou ask?

IAGO. But for a satisfaction of my thought,

No further harm.

OTHELLO. Why of thy thought, Iago?

IAGO. I did not think he had been acquainted with her.

OTHELLO. $O$ yes, and went between us very oft.

IAGO. Indeed?

OTHELLO. Indeed? Ay, indeed. Discern'st thou aught in that?

Is he not honest?

IAGO. Honest, my lord?

OTHELLO. Honest? Ay, Honest.

IAGO. My lord, for aught I know.

Othello, III.iii.96-108

Here or later, knowledge cannot be acquired through any of the usual mechanisms (asking, thinking, repeating, citing evidence); the mechanisms themselves are merely self-reflexive and self-perpetuating. Knowledge ultimately fails altogether:

IAGO. Demand me nothing. What you know, you know.

From this time forth I never will speak word.

Othello, V.ii.309-310

In Vurt, however, genuine, real-life encounters supersede rhetorical, staged, or scripted knowledge. When Scribble thinks he is playing the dangerous game feather, "Takshaka Yellow", a game whose premise is a thoroughly Anglicized version of a Hindu myth, the Game Cat interrupts him furiously. The Cat is angry because Scribble was only in a meta-feather, a cheap and pirated copy, just as his knowledge of Hindu mythology and "all the scents of India" and "its saffron-drenched pleasures" turn out to be superficial. ${ }^{47}$ In fact, the Cat reveals, Takshaka Yellow is a hidden Copvurt: the cops use the game to track down criminals and their felonies in both the real and Vurt worlds.

Vurt's version differs from the traditional myth, of which Jean-Phillippe Vogel gives several versions in Indian Serpent-lore: Or, The Nāgas in Hindu Legend and Art. Having served his guru Veda faithfully and learned the scriptures from him, the brahmin boy Uttanka offers to bring his guru the earrings of the queen for his pupil-fee. Uttanka successfully concludes many adventures on his way to the court but cannot bring back the queen's earrings immediately because of a contaminating mishap concerning nourishment (in some versions of the story he fails to observe ritual purity by neglecting to wash his hands after eating, or serves his guru a meal contaminated with 
a hair; in another set he pauses to take refreshment and the earrings fall out of their hiding place on to a snake's mound; in still another he is compelled to eat cow-dung by a giant). While Uttanka is distracted, the King of the Snakes, Takshaka, steals the earrings. Uttanka pursues Takshaka to Naagaland, the country of the serpents, where he is immune to their venom, thanks to that impure meal that he ate (in some versions, the contaminating influence is a horse upon which he must blow; he learns to ignore his "disgust" by telling himself that the animal is the vehicle of the fire-lord, Agni, and he is therefore merely blowing upon a flame). Thus contamination is responsible for Uttanka's failure but also for his success. ${ }^{48}$

Uttanka's body is contaminated by various waste products (old food, snake eggs, hair, dung) or externae, some of which (the hair and the dung) are also what early moderns would call excrements. Vurt reworks both this myth and what Ben Saunders calls the excremental "proto-racist [...] logic" of Othello. ${ }^{49}$ Saunders argues that Iago returns compulsively to the rhetoric of "compulsive anality":

[T] he virulence of racist strategies of "othering" [...] both objectify and abject-ify the targets of racial hatred [... through] a linguistic nexus that links the ideology of cultural superiority and the claim, by a particular gender or race, to the status of the "civilized" through the achievement of proper waste management [...]. The primary rhetorical means by which Iago (and others) force Othello back to his "true" marginalized "black" position involves an emphasis on filth, dirt, and excrement..$^{50}$

But Scribble must traverse Turdsville and conquer his retching aversion to roboman Barney and dogman Tristan, and develop compassion for the hideous Thing-fromOuter-Space. Furthermore, in Scribble's version of the Uttanka myth, the brahmin boy becomes "the Asian student" and the earrings belong to the queen of England, forged by the king "out of the most precious ore", ${ }^{51}$ possibly a reference to the Koh-I-Noor or star of India, the large Indian diamond taken by Queen Victoria for her Crown Jewels. And Takshaka, King of Snakes and cops, can only be defeated through the combined forces of the Game Cat, Scribble, "The Asian kids [...] cheering us on" and an unknown, "smiling" Asian man, during the novel's climax in Platt Fields park, near "the curry chute". ${ }^{22}$ (The "curry chute" is Noon's Vurtual transformation of the so-called "curry mile" in Manchester, a length of Wilmslow Road legendary for the variety of its Indian and Pakistani restaurants.) While Beetle resists until the last moment to admit that he has been hybridized by the Mandel bullet whose fractal virus ultimately kills him in a blaze of technicolor glory ("Not me... I'm pure... Tell me I'm pure"), Scribble finally realizes that the shifting rules of the Vurt favor those who are mixed and who use their hybridity, as Game Cat insists: “You've got the Vurt inside you... you don't need feathers", he explains.$^{53}$ Like L. Frank Baum's Dorothy with her silver slippers, Scribble possessed the secret key to the other world all along. Even Shaka, the shadowcop, can see it: "THERE'S SOME VIPER" (the snake poison that hybridized Scribble in the first place) "IN YOUR SYSTEM, LITTLE ONE". ${ }^{54}$ Corruption, contamination, hybridity, and even filth redeem Scribble and Desdemona.

It is only by acknowledging that he has been hybridized, rendered partly Vurtual, by his snakebite, and by accepting help from the Game Cat, from Tristan, who boasts "just a trace of dog", and from the "smiling Asian" man that Scribble can ultimately defeat the shadowcop, destroy the vurtsnake, and rescue Desdemona..$^{55}$ Dogman Tristan finds the Curious Yellow feather; in the Vurt, the Game Cat catches the falling Scribble, erases the police list of Stash Rider crimes and kills the demonic Takshaka copsnake, 
cradling Scribble in "soft arms... raising [him] up... calling to [him] softly, from the dream's mouth". ${ }^{56}$ In the real world, a group of joyful Asian youths chase away the reallife policeman (stealing his clothes and surrounding him). Structurally, the "smiling" Asian Muslim man in Platt Fields park leads Scribble to a kind of Enlightenment and directly replaces the Game Cat:

I felt a strong hand clutching under my shoulder, and then lifting me up, until I was looking direct into this Asian face. The rain was dripping all over his colour, like rain in the dusk. His black hair was wetted down all over his eyes, but I could see the life in them, the energy.

"Go for it, mate," he said. "Whatever it is." 57

Part of Scribble's enlightenment includes an awareness of religious diversity, of different beliefs among what had previously seemed to him like a homogenous community. "The Asians were high on Eid, and young Asian life pulsed through them," concludes Scribble; the young Muslims are celebrating Eid, the end of Ramadan, the season during which devout Muslims fast during the day, "feathered up" without feathers. ${ }^{58}$ At first amazed by the rejoicing around him at the death of the Snake King Takshaka, he concludes that it is "[b]ecause the Takshaka was a Hindu, and these kids were Muslims, and that's a world of difference." ${ }^{59}$

\section{Race and the Fantastic}

The unnamed Muslim man, like the Game Cat, becomes the narrative superhelper, a deus ex machina, and like all superhelpers, arrives and leaves mysteriously: "I took the young man's hand in mine. He smiled....'You do good, now,' the Asian said, and then walked away, into the rain". ${ }^{60}$ Later novels in the series emphasize this multiracial aspect of the Vurt's creation. Nymphomation explains aspects of the Vurt world; the hero of that novel, and inventor of Vaz, universal lubricant, contraceptive and elixir of life, is an Asian man, this time named: Jazir Malik, nicknamed Jaz. Keith Vaz was Britain's first Asian Member of Parliament; is Jaz's invention a Noonian joke at the M.P.'s expense, a sly comment on the illicit or sexual acts for which users employ the petroleum jelly Vaseline, or both?

Hand-in-hand with the nameless Asian man, Scribble at last understands how to reach Desdemona, still trapped in Curious Yellow. Once in Curious Yellow, however, sublime sibling-sex proves impossible, interrupted by paternal fury, by the Game Cat, and finally by the laws of the Vurt. Vurt does, however, have a happy ending, albeit an ambiguous and unexpected one. Scribble does rescue Desdemona. But the "traffic in women" is reversed by the laws of the Vurt: in order to save Desdemona, Scribble has to exchange her for an object of equal or greater value-himself. The Vurt banishes endogamy and insularity in favor of exogamy (restored to the real world, Desdemona eventually takes another lover, one to whom she is unrelated) and crossing over (in a geographical sense, across the districts of Manchester, and in a Vurtual sense, as Scribble traverses the Vurtual world).

We can again helpfully parallel Wenaus's "paraspace" with what we could call a fractal "paratime": Todorov's fantastic. The fantastic oscillates between past and future to create a precarious present:

The marvelous corresponds to an unknown phenomenon, never seen as yet, still to come-hence to a future; in the uncanny, on the other hand, we refer the inexplicable to known facts, to a previous experience, and thereby to the past. ${ }^{61}$ 
The time-scheme of Othello, too, is notoriously marvelous: if plotted logically, there is no where and no when for Desdemona to have "with Cassio [...] the act of shame / A thousand times committed" (V.ii.209-210). As Michael Neil suggests, the plot unfolds in strict time even as the action unfolds in a kind of "temporal limbo". ${ }^{62}$ Similarly, the Vurt repeats itself endlessly (as do Noon's narrative and the inescapable meta-Vurts) even as the real-life Desdemona, Scribble's lost love, ages in biological time and in her biological body each time that Scribble (trapped now in turn, within the Vurt) sees her play his feather.

32 I began by suggesting that Vurt hesitates between the uncanny and the marvelous, as does its understanding of race, but perhaps it goes further. As Todorov argues, "the 'normal' [we might say, here, or even in Othello, the 'pure'] man is precisely the fantastic being; the fantastic becomes the rule, not the exception". ${ }^{63}$ The real world is as fantastic, as dream-filled, as the Vurtual, and Scribble's hesitation between purity and hybridity is the "hesitation" between real and imaginary worlds. In this sense Noon's grotesque, obscene, profane, transcendent cyberpunk fantasy does not rewrite Shakespeare as much as unmask the power of Othello to create and destroy the power of race and racial myth-making. There is a sense in which race itself is the fantastic category, the "evanescent genre", a category that seems to have an ontology, to recall (uncannily) something real, but at the same time to be entirely fictional, a species of the marvelous.

\section{NOTES}

1. I would like to thank Laetitia Sansonetti and the anonymous readers for the journal for their bracing comments; Simone Broders, the convenor of the panel at Shakespeare 450 where a version of this paper was presented; and the Modern Language Association of America Discussion Group on Science Fiction and the Fantastic, which heard the earliest draft of this paper in 2000 at a panel chaired by Alcena Rogan.

2. Jeff Noon, Pixel Juice: Stories from the Avant-Pulp, London, Black Swan, 2000; see also Noon's "Description of an Avant-Pulp Machine, with Tweets," 2013, captured on Storify by Matt Canale <https://storify.com/mattcanale/jeffnoon-description-of-an-avant-pulp-machine>, accessed October 1, 2015.

3. Donna Haraway, "A Cyborg Manifesto: Science, Technology, and Socialist-Feminism in the Late Twentieth Century", in Simians, Cyborgs and Women: The Reinvention of Nature, New York, Routledge, 1991, p.149-181; N. Katherine Hayles, How We Became Posthuman: Virtual Bodies in Cybernetics, Literature, and Informatics, Chicago, University Of Chicago Press, 1999; William Gibson, Neuromancer, New York, Ace, 1984, p. 6, 9, 37, 155 et passim.

4. N. Katherine Hayles, My Mother Was a Computer: Digital Subjects and Literary Texts, Chicago, University of Chicago Press, 2005, esp. Chapter 8, "Simulating Narratives: What Virtual Creatures Can Teach Us", p. 193-213.

5. Vilgot Sjöman, dir., I Am Curious (Yellow), Janus Films, 1967; Jeff Noon, Pollen, Manchester, Ringpull, 1995, The Automated Alice, London, Doubleday, 1996, Nymphomation, London, Doubleday, 1997. 
6. Noon, Vurt, op. cit, p. 266.

7. Daniel Gilbert, Stumbling Upon Happiness, New York, Vintage, 2007, p. 3 and passim.

8. Koko the gorilla learned a kind of sign language and Alex the grey parrot used words referentially, although whether they were able to understand syntax remains controversial; gorillas in the wild stripped bark and leaves from twigs in order to use them as "fishing rods " for termites and other insects; a wild Japanese snow monkey washed sweet potatoes in sea water, a recipe that she taught her children and that in turn encouraged the colony to wash wheat in sea water, to consume sea vegetables, and to swim in the sea in what one commentator identifies as a Kuhnian "paradigm shift." On Alex the parrot, see Irene Maxine Pepperberg, The Alex Studies: Cognitive and Communicative Abilities of Grey Parrots, Cambridge, MA, Harvard University Press, 1999. Monkeys fishing for termites can be viewed via the Jane Goodall Institute <http:// vimeo.com/5002231>, accessed January 3, 2015. On Koko the gorilla, see Francine Patterson and Wendy Gordon, "The Case for the Personhood of Gorillas", in The Great Ape Project: Equality Beyond Humanity, edited by Paola Cavalieri and Peter Singer, London, Macmillan, 1993, p. 58-77, or the more skeptical James L. Newman, "Famous Gorillas", in Encountering Gorillas: A Chronicle of Discovery, Exploitation, Understanding and Survival, Plymouth, UK, Rowman and Littlefield, 2013, p. 113-146. The behavior of the Koshima macaques or snow monkeys has been widely documented; see, for example, Kevin N. Laland and Bennett G. Galef, "Introduction", The Question of Animal Culture, Cambridge, MA, Harvard University Press, 2009, p. 3-5 for references. The application of Thomas Kuhn's phrase "paradigm shift" to macaque behavior comes from Elaine Myers' rebuttal of the "Hundredth Monkey" concept in so-called New Age thinking, reprinted in The Encyclopedic Sourcebook of New Age Religions, edited by James R. Lewis, Amherst, New York, Prometheus Books, 2004, p. 605.

9. Gilbert, op. cit.

10. See Kathryn Cramer, "Hard Science Fiction" in The Cambridge Companion to Science-Fiction, Cambridge, Cambridge University Press, 2003, p. 186-196, p. 194.

11. Jacques Derrida, "That Dangerous Supplement", in Of Grammatology, trans. Gayatri Spivak, Baltimore, MD, Johns Hopkins University Press, 1997, p. 141-164.

12. Othello, III.iii.408 and IV.i.265; I.i.88, I.i.115, I.iii.335-6. These and subsequent quotations from Othello are taken from the Oxford Shakespeare, edited by Stanley Wells and Gary Taylor, Oxford, Oxford University Press, 1986.

13. Steven Swarbrick, "Shakespeare's Blush, or 'the Animal' in Othello", forthcoming in Exemplaria 28.2 (2016). I thank Mr. Swarbrick for allowing me to read and reference the copy-edited manuscript of his essay.

14. See Rebecca Ann Bach's important essay "Bearbaiting, Dominion, and Colonialism", in the collection Race, Ethnicity, and Power in the Renaissance, edited by Joyce Green MacDonald, Madison, NJ, Fairleigh Dickinson University Press, 1997, p. 19-35. Bruce Boehrer connects the ill-treatment of animals to the wielding of colonial, gendered, and racial power over othered human subjects in the introduction to his Shakespeare Among the Animals, New York and Houndmills, UK, Palgrave Macmillan, 2002, p. 1-40. Laurie Shannon's The Accommodated Animal: Cosmopolity in Shakespearean Locales, Chicago, University of Chicago Press, 2013, sensitively reads early modern humans in King Lear as "unaccommodated man", humanly insufficient in contrast to the animals whose hides and shells protect them from the elements, p. 127-173.

15. Joel Altman, The Improbability of Othello: Rhetorical Anthropology And Shakespearean Selfhood, Chicago, IL, University of Chicago Press, 2010.

16. Swarbrick, op. cit.

17. David Houston Wood, “Fluster'd with flowing cups': Alcoholism, Humoralism, and the Prosthetic Narrative in Othello", Disability Studies Quarterly 29.4 (2009): http://dsq-sds.org/article/ view/998/1182, accessed October 15, 2015. 
18. Tzvetan Todorov, The Fantastic: A Structural Approach to a Literary Genre, trans. Richard Howard and introd. Robert Scholes, Ithaca, NY, Cornell University Press, 1993, p. 171, p. 172.

19. Linda Hutcheon, with Siobhan O'Flynn, A Theory of Adaptation, $2^{\text {nd }}$ edition, London, Routledge, 2012, p. 171, p. 181.

20. Gary R. Bortolotti and Linda Hutcheon, "On the Origin of Adaptations: Rethinking Fidelity Discourse and 'Success'-Biologically”, New Literary History 38.3 (2007): 443-58.

21. Christy Desmet and Sujata Iyengar, "Adaptation, Appropriation, or What You Will", Adaptation (2015), p. 3, DOI: 10.1080/17450918.2015.1012550, accessed 25 February 2015.

22. Douglas Lanier, "Shakespearean Rhizomatics: Adaptation, Ethics, Value", Shakespeare and the Ethics of Appropriation, edited by Alexa Huang and Elizabeth Rivlin, New York, Palgrave, 2014, p. 21-40, p. 27 et passim, quoted in Desmet and Iyengar, op. cit., p. 3.

23. Desmet and Iyengar, op. cit., p. 5.

24. Todorov, op. cit., p. 42-44.

25. Ibid., p. 42, p. 173.

26. Ibid., p. 44.

27. Noon, Vurt, op. cit., p. 129.

28. Jay David Boulter and Richard Grusin, Remediation: Understanding New Media, Cambridge, MA, MIT Press, 2000.

29. Susan Snyder famously identified Othello's subversion of the structure of romantic comedy. Susan Snyder, "Othello and the Conventions of Romantic Comedy", Renaissance Drama 5 (1974): 123-141.

30. Manchester A-Z, Sevenoaks, Kent, Geographer's A-Z Map Company, Ltd., 1992; “Ethnic Groups in Manchester", Manchester Census 1991, Planning Studies Group Manchester City Council, Manchester, UK, November 1994.

31. François Laroque, "Shakespeare's Imaginary Geography", in Shakespeare and Renaissance Europe, edited by Andrew Hadfield and Paul Hammond, London, Bloomsbury, 2014, p. 216. On the possibly impossible journey to Cyprus, see esp. Sanders, introduction, op. cit., p. 4-5, 10-14.

32. Andrew Wenaus, “The Paradox Of Escape In Noon's Vurt," Science Fiction Studies 38 (2011), p. 160.

33. Patricia Parker, "Preposterous Events," Shakespeare Quarterly 43 (1992): 186-213, p. 207, p. 208.

34. Dennis Britton, Becoming Christian: Race, Reformation, and Early Modern English Romance, New York, Fordham University Press, 2014.

35. Noon, Vurt, op. cit., p. 106.

36. Ibid., p. 236.

37. Ibid., p. 65.

38. Ibid., p. 304.

39. Ibid.

40. For the association of Iago with "honesty" see II.iii.169, II.iii.320, et passim. A rich and varied scholarship exists on race in the early modern period and in Shakespeare's Othello. Useful starting-points include Margo Hendricks and Patricia Parker, editors, Women, "Race", and Writing in the Early Modern Period, New York and London, Routledge, 1994; Virginia Mason Vaughan's Othello: A Contextual History, Cambridge, Cambridge University Press, 1996; Mythili Kaul, editor, Othello: New Essays by Black Writers, Washington, DC, Howard University Press, 1997; Philip Kolin, editor, Othello: New Critical Essays, New York and London, Routledge, 2002; Kim F. Hall, editor, Othello, the Moor of Venice: Texts and Contexts, Boston, Bedford/St. Martin's, 2007, and the scholarly editions of E.A.J. Honigmann, London, Arden Shakespeare, Third Series, 1997, Norman Sanders, Cambridge, Cambridge University Press, 2003, and Michael Neill, Oxford, Oxford World's Classics, 2008. 
41. Gayle Rubin, "The Traffic in Women: Notes on the "political economy of sex", Toward an Anthropology of Women, edited by Rayna R. Reiter, New York, Monthly Review Press, 1975, p. 157-210.

42. Noon, Vurt, op. cit, p. 190.

43. Ibid., passim.

44. Ibid., p. 131.

45. Ibid., p. 157, p. 163.

46. Ibid., p. 257.

47. Ibid., p. 184, p. 185.

48. Jean-Phillippe Vogel, Indian Serpent-lore: Or, The Nāgas in Hindu Legend and Art, Varanasi, Indiological Book House, 1972, p. 61-66.

49. Saunders, Ben. "Iago's Clyster: Purgation, Anality, and the Civilizing Process", Shakespeare Quarterly 55 (2004): 148-176.

50. Saunders, op. cit., p. 158, p. 164-167.

51. Noon, Vurt, op. cit., p. 184.

52. Ibid., p. 305.

53. Ibid., p. 213, p. 147.

54. Ibid., p. 114.

55. Ibid., p. 216, p. 147.

56. Ibid., p. 308.

57. Ibid., p. 304.

58. Ibid., p. 304.

59. Ibid., p. 305.

60. Ibid., p. 310.

61. Todorov, op. cit., p. 42.

62. Neill, ed., Othello, op. cit., p. 35.

63. Noon, Vurt, op. cit., p. 173.

\section{ABSTRACTS}

This paper argues that Jeff Noon's 1993 British cyberpunk novel Vurt rewrites Shakespeare's tragedy of exogamy or racial crossing, Othello, as a triumphant fable in favor of interspecies mixing. The novel moves among 1990s Manchester, the drug-fuelled, multi-species virtual gameworld or Vurt, and the deadly cultural crossings of Shakespeare's Othello. The gang whose exploits the narrator, Scribble, documents prides itself on its racial purity, to such an extent that Scribble is in love with his own sister, Desdemona. By the end of the novel, however, Scribble discovers that the world of the Vurt favors cross-cultural myth-making over antique Englishness and hybrid adaptation (in both its literary and racial senses) over generic or genetic purity.

Cet article suggère que le roman "cyberpunk" de Jeff Noon, Vurt, réécrit la tragédie shakespearienne de l'exogamie du croisement racial, Othello, comme une histoire de l'union triomphante entre des espèces et des races humaines. L'action du roman se déroule entre la ville de Manchester dans les années 1990, qui constitue l'univers virtuel de Vurt, fait de drogue, de jeux vidéo et de mélanges entre les espèces, et les rencontres culturelles mortelles représentées par Shakespeare dans son Othello. Le gang dont le narrateur, Scribble, raconte les exploits, 
s'enorgueillit de sa pureté raciale, à tel point que Scribble est amoureux de sa propre sœur, Desdemona. À la fin du roman, cependant, Scribble découvre que le Vurt favorise la production de mythes trans-culturels au détriment d'une anglicité traditionnelle et encourage l'hybridation (dans le domaine littéraire aussi bien que racial) plutôt que la pureté générique ou génétique.

INDEX

Keywords: 1990s, avant-pulp, cyberpunk, drugs, Englishness, Manchester, Noon Jeff, Othello, race, virtual reality, Vurt

Mots-clés: anglicité, années 1990, cyberpunk, drogue, Manchester, Noon Jeff, Othello, race, réalité virtuelle, Vurt

\section{AUTHOR}

SUJATA IYENGAR

University of Georgia 